\title{
PROCESY PRZYSWAJANIA, UCZENIA SIĘ I UŻYCIA JĘZYKA
}

\author{
MARIAN SZCZODROWSKI \\ Ateneum Szkoła Wyższa w Gdańsku \\ Wydział Neofilologiczny \\ ul. 3 Maja 25 A, 80-825 Gdańsk, Polska \\ e-mail:m.szczodrowski6@uppoczta.pl \\ (nadesłano: 18.04.2017; zaakceptowano 13.07.2017)
}

\section{Abstract \\ Processes of acquisition, learning, and using language}

This paper considers the following processes: (1) the acquisition of language by a child, who in stages masters a specific stock of vocabulary and grammatical rules, constructing at the same time his/her own linguistic store-mechanism; (2) learning the first language or a foreign language in educational circumstances, in which theoretical knowledge of the language system is acquired, and a theoretical knowledge of the development of communicative competences and abilities (c.f. first language), although in the case of a foreign language, the learner acquires organized lexical-grammatical material, which constitutes the basis for the receptive and productive use of it; (3) the use of language in daily communicative situations and in cognitive-research work, as a result of which the inventory of expressions in the used language increases.

\section{Key words}

Language acquisition $a b$ initio, competences and abilities, glottodidactics and its divisions, mental and linguistic products. 


\section{Abstrakt}

Przedmiotem rozważań są następujące procesy: (1) Przyswajania (akwizycji) języka przez dziecko, które opanowuje stopniowo określony zasób słownictwa i reguł gramatycznych, budując jednocześnie własny magazyn-mechanizm językowy. (2) Uczenia się języka ojczystego lub obcego w warunkach edukacyjnych, gdzie zdobywa się i wiedzę teoretyczną o systemie języka, i o doskonaleniu jego sprawności i umiejętności komunikacyjnych (por. język ojczysty), a w przypadku języka obcego uczący przyswaja uporządkowany materiał leksykalno-gramatyczny, stanowiący podstawę receptywnego i produktywnego operowania nim. (3) Posługiwania się językiem w codziennych sytuacjach komunikacyjnych oraz w pracy badawczo-poznawczej, w wyniku której powiększa się inwentarz wyrazów używanego języka.

\section{Słowa kluczowe}

Przyswajanie języka ab initio, sprawności i umiejętności, glottodydaktyka i jej podział, wytwory duchowe i językowe.

\section{Wprowadzenie}

Niniejsze rozważania na temat funkcjonowania języka dotyczą trzech procesów, w których, po pierwsze, dokonuje się jego przyswajanie (akwizycja) ab initio, tzn. osoba (tu dziecko), uczestnicząc w sytuacjach komunikacyjnych z członkami swojej wspólnoty językowej, nawiązuje $\mathrm{z}$ nimi kontakt najpierw receptywnie, a następnie stopniowo (re)produktywnie, opanowując w sposób świadomy zarówno stosowane słownictwo, jak i arefleksyjnie jego poszczególne struktury fonetyczno-fonematyczne oraz zasady gramatycznych powiązań pojedynczych wyrazów w syntagmatyczno-syntaktyczne konstrukcje. Takie czynności obcojęzyczne sprawiają, iż dany użytkownik $\mathrm{z}$ wolna konstruuje własny magazyn-mechanizm języka, który wyposażony w receptywno-produktywne umiejętności i sprawności umożliwia posługiwanie się nim w kontaktach z współpartnerami swojej wspólnoty językowej. Jest to proces systematycznego opanowywania języka ojczystego przez dziecko już we wczesnym okresie postnatalnym. Tu jednak pojawia się następujący problem, a mianowicie dziecko przyswaja taki język, jakim operują członkowie jego wspólnoty językowej. W takim przypadku nasuwa się pytanie, jakiego języka używają członkowie tejże wspólnoty, tzn. czy przestrzegają norm języka literackiego, czy używają również form środowiskowych i/ lub terytorialnych języka?!

Po drugie, nauka jakiegokolwiek języka i ojczystego, i obcego polega również na jego uczeniu się w różnych warunkach sytuacyjno-komunikacyjnych, a szczególnie zaś w zorganizowanym systemie edukacyjnym, gdzie - ogólnie rzecz ujmując - uczący się nabywają i systematyzują zarówno potrzebną wiedzę teoretyczną o systemie norm w nim obowiązujących, jak i o praktycznym ich zastosowaniu w trakcie mówienia i pisania, w których to czynnościach dokonuje się ugruntowanie nie tylko wiedzy o ję- 
zyku, lecz także biegłości w jego użyciu jako środka porozumiewania się ustnego i pisemnego.

Trzeci proces wiąże się właśnie z wyżej wymienionymi zagadnieniami, czyli ze sprawnościami i umiejętnościami prawidłowego i starannego stosowania języka podczas mówienia i pisania, a także uważnego słuchania i zrozumienia przekazywanych przez rozmówców informacji oraz czytania ze zrozumieniem (literackich i specjalistycznych) tekstów.

A zatem dokładniejsza charakterystyka wymienionych procesów językowych wskaże na istotne właściwości wybranych stadiów ich informacyjno-komunikacyjnego przebiegu.

\section{Proces przyswajania języka}

Przyswajanie języka dokonuje się poprzez (bardzo) częsty kontakt danego użytkownika z członkami tej samej wspólnoty językowej, co skutkuje tym, iż po pewnym czasie odbierane i dekodowane w procesie informacyjno-komunikacyjnym struktury fonetyczno-fonematyczne, słownikowe i gramatyczne zostają arefleksyjnie opanowane i ukształtowane $\mathrm{w}$ językowym magazynie-urządzeniu jako prawie że trwałe matryce najpierw w sposób receptywny, następnie reproduktywny, i - w końcu - produktywny.

Istota procesu opanowywania języka przejawia się również w tym, iż prawidłowość przyswojonych i w dalszym ciągu przyswajanych struktur poddana zostaje zarówno kontroli, jak i - jeśli zachodzi taka konieczność - korekcie najpierw (jeśli to możliwe) ze strony jego najbliższych użytkowników, a następnie fachowej ocenie ich poprawności wraz z wymaganą korektą występujących błędów lub nieprawidłowości w zinstytucjonalizowanym (szkolnym) systemie edukacyjnym. Oprócz wyszczególnionych czynności należy jeszcze wymienić zachodzący u niektórych użytkowników proces autokontroli i autokorekty podczas recepcji, reprodukcji i produkcji opanowanych i nowo przyswajanych struktur językowych. Wszystkim wymienionym procesom towarzyszy $\mathrm{w}$ różnym stopniu dokonujące się przetwarzanie materiału językowego, polegające na analizie szczególnie tych struktur, które podczas ich semantyczno-gramatycznego dekodowania umożliwiają ich efektywne zakodowanie (przechowanie) w określonej pamięci danego użytkownika ${ }^{1}$.

Proces nabywania jakiegokolwiek języka dokonuje się podczas przebywania jego użytkownika w środowisku, w którym dany język stanowi środek porozumiewania się, oraz jego równoczesnego uczestniczenia receptywnego, reproduktywnego i produktywnego w sytuacjach lingwo-komunikacyjnych. Są to zatem naturalne warunki przyswajania języka, czyli podobne do tych, w których dziecko opanowuje swój język, a więc inne od tzw. 'sztucznych warunków' nauki języków obcych². Dziecko przyswaja język ojczysty w określonym okresie swojego życia na podstawie specyficznego i już odpowiednio rozwiniętego mechanizmu odbioru i przetwarzania dekodowanych

\footnotetext{
1 H. Strohner. Textverstehen, Kognitive und kommunikative Grundlagen der Sprachverarbeitung. Opladen: Westdeutscher Verlag, 1990, s. 25.

2 V. Beeh. Sprache und Spracherlernung. Unter mathematisch-biologischer Perspektive. Berlin-New York: Walter de Gruyter, 1981, s. 115.
} 
struktur, czyli bez konieczności formalnego i merytorycznego instruktażu glottodydaktycznego. Naukę języków obcych w systemie zorganizowanej edukacji pobierają uczący się (młodzież szkolna, akademicka i dorośli), którzy opanowali już swój język ojczysty, a przyswajanie języków obcych w zinstytucjonalizowanych warunkach wymaga systematycznego nauczania i uczenia się. Nauczyciel lub lektor języka obcego, podręczniki i materiały glottodydaktyczne, stosowane metody stanowią podstawowe czynniki odróżniające naukę tych języków od procesu przyswajania języka ojczyste$\mathrm{go}^{3}$. Ponadto opanowywanie języka realizuje się również $\mathrm{w}$ procesie indywidualnego i świadomego samokształcenia, a w warunkach zinstytucjonalizowanych wynika on w wielu przypadkach, szczególnie zaś w szkolnej edukacji, z procesu nauczania. A zatem właściwości procesu przyswajania języków w ogóle, tzn. języków ojczystych i obcych, dają się porównać ze zjawiskiem nabywania języka podczas operowania nim w bezpośredniej komunikacji międzyludzkiej lub w trakcie jego indywidualnego użycia, na przykład podczas czytania albo pisania, a także w sytuacjach glottodydaktycznych, gdzie język stanowi i przedmiot nauki, i zarazem środek porozumiewania się.

Druga ważna konstatacja odnosi się do następującego zagadnienia: Osoba rozpoczynająca naukę języka obcego albo kontynuująca tenże proces jest już użytkownikiem swojego języka ojczystego, a może być także użytkownikiem kilku języków ojczystych i/lub obcych. W odniesieniu do osób władających jednym lub kilkoma językami ojczystymi można przyjąć podział na użytkowników monolingwalnych, bilingwalnych, trilingwalnych itd., a wobec osób posługujących się jednym lub kilkoma językami obcymi stosuje się niekiedy określenia: pierwszy, drugi, trzeci itd. język obcy. Trzeba jednak podkreślić, iż istnieje zasadnicza różnica między stwierdzeniem, iż dana osoba operuje językiem ojczystym albo obcym. Po pierwsze, rodzimi użytkownicy języka opanowali go w warunkach naturalnych, w których ów język był i jest na co dzień środkiem międzyludzkiego porozumiewania się. Po drugie, różnica ta tkwi w zakresie oraz poziomie przyswojenia określonych sprawności i umiejętności językowych, i wreszcie, po trzecie, inna jest biegłość szczególnie w mowie u rodzimych użytkowników języka/języków, a inna u tych, którzy zdobyli sprawności i umiejętności obcojęzyczne $\mathrm{w}$ procesach zorganizowanej edukacji, gdzie przywiązuje się wagę do prawidłowego opanowania języka pod względem gramatycznym, stylistycznym, ortograficznym, interpunkcyjnym, a także - jeśli zachodzi taka konieczność i istnieje możliwość - do przestrzegania i stosowania zasad ortoepii i ortofonii ${ }^{4}$. Może się jednak zdarzyć, że uczący się języka obcego po pewnym czasie opanuje go lepiej niż swój ojczysty, a jego kompetencja lingwo-komunikacyjna przewyższa kompetencję prymarnojęzykową, czyli ojczystojęzyczną.

\footnotetext{
3 Zob. także S.W. Felix. Psycholinguistische Aspekte des Zweitsprachenerwerbs. Tübingen: Gunter Narr Verlag, 1982, s. 126 i n.

4 Por. H.J. Vollmer. Spracherwerb und Sprachbeherrschung. Tübingen: Gunter Narr Verlag, 1982, s. 153.
} 


\section{Proces uczenia się języka}

Każda naukowa koncepcja systematyzująca wyniki badań, uzyskane dzięki poznaniu i wyjaśnianiu podstawowych czynników kształtujących procesy nauki języka, stanowi jednocześnie część teorii, która nawiązuje do dotychczas istniejących poglądów na temat nauczania, uczenia się i przyswajania języków w ogóle. Taka teoria analizuje i opisuje wymienione procesy i przybiera tym samym charakter diagnozujący (rozpoznawczy) w odniesieniu do czynników konstytuujących określony proces glottodydaktyczny i funkcjonujących równocześnie w jego przebiegu.

Skoro zaś rozważa się związki glottodydaktycznej teorii z zagadnieniami glottodydaktycznej praktyki, a wśród nich metody jej efektywności, to należy uwzględnić różne sposoby postępowania nauczającego i uczących się oraz ich sprawności i umiejętności komunikacyjne, a także stosowane środki dydaktyczno-metodyczne prowadzące do osiągnięcia wyznaczonego celu. Takie formy glottodydaktycznej działalności przybierają charakter prognozujący, polegający na przewidywaniu możliwego przebiegu cząstkowego procesu glottodydaktycznego. Glottodydaktyczna przewidywalność wynika z formułowanych przesłanek teoretycznych i praktycznych, sprzyjających stwarzaniu optymalnych warunków nauczania i uczenia się języków, a także uwzględniających możliwości osiągnięcia zamierzonego celu w określonych sytuacjach przebiegu tychże procesów.

Rozpatrując kwestie przyswajania języków z punktu widzenia glottodydaktycznego, a także badając procesy opano(wy)wania języka ojczystego w sytuacjach naturalnych oraz procesy nauczania i uczenia się języków obcych w warunkach zinstytucjonalizowanych, można zastosować nieco inny podział nauki języków. Ogólna glottodydaktyka językowa obejmuje naukę języka ojczystego i języków obcych, a w zakresie tych ostatnich wyróżnia się języki klasyczne (greka, łacina) i języki nowożytne (na przykład: język angielski, francuski, hiszpański, niemiecki, rosyjski itd.). Dodać należy jeszcze, że glottodydaktyka językowa włącza do swojego programu badawczego również metody nauki tzw. języków sztucznych, które jako języki pomocnicze funkcjonują w międzynarodowej komunikacji (por. esperanto, ido, novial, occidental, volapük). Zatem uzupełniona klasyfikacja języków w świetle glottodydaktyki obejmuje (lub może obejmować) badania w zakresie:

1. glottodydaktyki ojczystojęzycznej,

2. glottodydaktyki obcojęzycznej (w tej subdziedzinie należy rozgraniczyć dydaktykę języków nowożytnych od dydaktyki języków klasycznych),

3. glottodydaktyki języków sztucznych.

W niniejszych rozważaniach glottodydaktycznych bierzemy pod uwagę osoby, które władają (jednym) językiem ojczystym i pobierają naukę pierwszego języka obcego. Zakładamy jednocześnie, że te osoby opanowały swój język ojczysty w mowie i piśmie w taki sposób, iż potrafią nim bez trudności operować w komunikacji międzyludzkiej.

W rozważaniach na temat przyswajania i uczenia się języka ważny jest fakt, gdyż odnosi się do istoty przechowania (magazynowania) dekodowanych struktur językowych w odpowiedniej pamięci uczącego się. Carel F. Parreren ${ }^{5}$ rozpatrując powyższe

5 C.F. van Parreren. Lernprozeß und Lernerfolg. Braunschweig: Georg Westermann Verlag, 1972, s. 297. 
zagadnienia, odwołuje się do psychologii uczenia się, gdzie rezultaty tego procesu sprowadza się do pojęcia pozostawionego w pamięci „śladu” („Spur”, konkretniej „Gedächtnisspur”). Rezultat uczenia się interpretuje w dwojaki sposób: raz jako aktualne działanie językowe, drugi raz jako potencjalną zdolność odbiorczo-wytwórczą tkwiącą w umyśle (w urządzeniu językowym) człowieka, która może się objawić w określonych warunkach kontaktu językowego. Pojęcie śladu jest bliskie pojęciu matrycy językowej w ujęciu Ludwika Zabrockiego ${ }^{6}$, gdy przedstawia i wyjaśnia istotne cechy cybernetycznych modeli językowej komunikacji. Wracając do efektów procesu uczenia się i przyswajania języka, warto uświadomić sobie, iż w umyśle odbiorcy zostaje odciśnięty określony znak, a w tym przypadku jest to znak językowy o charakterystycznej cesze i konkretnej informacji. W koncepcji Parreren'a ${ }^{7}$ ślad w pamięci gwarantuje konsekwentną ciągłość działania odbiorcy, tzn. osiąga sprawność rozpozna(wa)nia struktur fonetyczno-fonologicznych lub graficzno-grafematycznych $\mathrm{w}$ jego receptorach (= zdolność do retencji), a także zdolność reprodukowania dekodowanych informacji. $\mathrm{W}$ odniesieniu do procesu uczenia się języka i jego receptywno-produktywnych następstw konstruuje ciąg składający się z czterech następujących ogniw (rys. 1):

Proces uczenia się

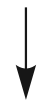

Powstały i ukształtowany ślad w pamięci

jako rezultat tegoż procesu

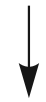

Retencja jako właściwość reprodukowania i rozpoznawania

zmagazynowanych struktur języka

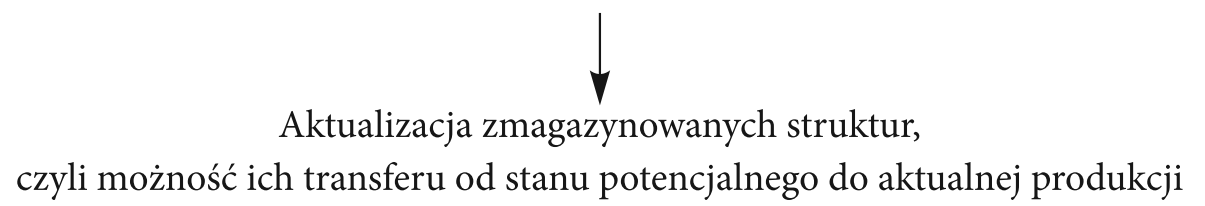

Rys. 1. Fazy receptywno-produktywne procesu uczenia się języka obcego według koncepcji C.F. van Parreren'a.

Źródło: opracowanie własne.

\section{Proces użycia języka}

Kwestia stosowania języka wiąże się raz ze swobodnym operowaniem nim w powstałych lub tworzących się sytuacjach komunikacyjnych, a drugi raz z twórczą działalnością badawczo-poznawczą jego użytkownika, gdy w trakcie takiej czynności odkrywa dotychczas nieznany fragment rzeczywistości pozajęzykowej i równocześnie przyporządkowuje mu nową nazwę, która najpierw uzyskuje akceptację u bezpośred-

\footnotetext{
${ }^{6}$ L. Zabrocki. Kybernetische Modelle der sprachlichen Kommunikation. Wrocław-Warszawa-Kraków-Gdańsk: Ossolineum, 1975, s. 42 i n. oraz 80 i n.

7 C.F. van Parreren. Lernprozeß und Lernerfolg..., s. 297.
} 
nich odbiorców/partnerów komunikacyjnych, następnie w szerszym kręgu członków swojej wspólnoty językowej, co powoduje wzbogacenie dotychczas istniejącego inwentarza słownikowego danego języka. Postęp wiedzy ogólnej i specyficznej pociąga za sobą również rozwój inwentarza języka i jego komunikacyjne doskonalenie.

Z powyższych konstatacji wynika, iż czynności językowe danej osoby można rozpatrywać na kilku płaszczyznach i w wielu wymiarach, na przykład:

1. W codziennej działalności członków danej wspólnoty ojczystojęzycznej w różnych okolicznościach życiowych i zawodowych;

2. W sytuacjach glottodydaktycznych, w których odbywa się nauka (nauczanie i uczenie się) języka ojczystego albo języka obcego;

3. Na płaszczyźnie intraindywidualnej w trakcie pracy poznawczo-badawczej, gdzie w obiegu egocentrycznej komunikacji zachodzi specyficzny proces użycia języka; ${ }^{8}$

4. Podczas receptywnych czynności słuchania ze zrozumieniem albo czytania ze zrozumieniem;

5. Podczas produktywnych czynności mówienia (w wypowiedziach monologowych, dialogowych, polilogowych, recytacji itp.);

6. Podczas produktywnych czynności pisania różnego rodzaju tekstów;

7. W procesie tworzenia nowych wyrazów (neologizmów), odnoszących się do przyporządkowania im nazw dotychczas nieznanych przedmiotów, zjawisk lub ich właściwości.

Do niektórych powyższych czynności językowych ustosunkował się również Konrad Górski , gdy przedstawił i wyjaśnił zagadnienia wytworów duchowych i językowych danego użytkownika, wyszczególniając ich właściwości intraindywidualne, urzeczywistniające się w procesie generowania i produkowania, oraz właściwości interindywidualne, które „wyrażone i utrwalone oddzielają się od podmiotu czynności i nabierają charakteru obiektywnego bytu..., czyli stają się już częścią ogólnego inwentarza języka określonej wspólnoty. Podkreśla tym samym psychiczno-lingwalne czynności użytkownika języka, którego wytwory zostają uzewnętrznione i tym samym mogą być i/lub zostają utrwalone w znakowym systemie języka. W powyższej konstatacji dokonuje autor podwójnego rozróżnienia uzewnętrznionych wytworów na trwałe lub nietrwałe, a w wytworach utrwalonych wyróżnia ich stan aktualny, tzn. istniejący rzeczywiście w przestrzeni, oraz potencjalny, mogący ujawnić się w przyszłości podczas użycia języka.

Wytwory użytkowników języka stanowią zatem część ich wytworów duchowych, których binarno-modelowe uporządkowanie można przedstawić następująco (rys. 2):

Interpretując pojęcie wytwór uzewnętrzniony Konrad Górski ${ }^{10}$ nazywa go wytworem wyrażonym i dochodzi do definicji wyrazu, który służy do „przekazywania sta-

8 L. Jäger. Einführung in die Sprachtheorie. „Linguistik und Didaktik” 1980, nr 41, s. 7.

9 Autor powołuje się na wyróżnienie wytworów dokonane przez Kazimierza Twardowskiego w rozprawie O czynnościach $i$ wytworach (Księga pamiątkowa ku uczczeniu 250 rocznicy założenia Uniwersytetu Lwowskiego, LL, Lwów 1912, a także w formie przedruku Rozprawy i artykuły filozoficzne, Lwów 1927). Zaznacza również, iż różni się od K. Twardowskiego w kwestii podziału wytworów i licznych ich szczegółów (zob. Konrad Górski 1984, s. 14, przypis).

10 K. Górski. Rozważania teoretyczne. Literatura - Muzyka - Teatr. Lublin: Katolicki Uniwersytet 


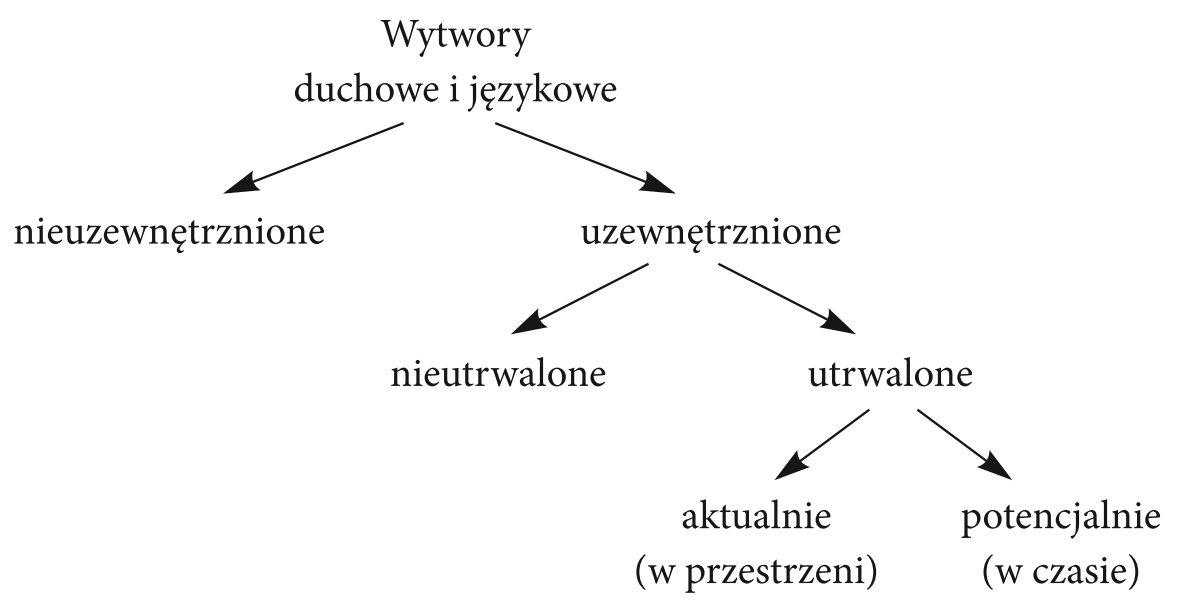

Rys. 2. Podział wytworów duchowych i językowych na podstawie koncepcji K. Górskiego. Źródło: opracowanie własne.

nów psychicznych lub treści duchowej (...) za pomocą odpowiednich zmysłowo dostrzegalnych znaków".

Intraindywidualny proces językowy nadawcy jest ściśle sprzężony z procesem mentalnym, podczas którego pojawia się określony zamysł komunikacyjny, a ten z kolei przekazany na zasadzie samosterowania do urządzenia językowego powoduje, iż dochodzi do wyboru korespondujących z nim i odpowiadających mu wyrazów oraz ich łączenia (konkatenacji) w konstrukcje syntagmatyczno-syntaktyczne ${ }^{11}$. W ten sposób dokonuje się w urządzeniu językowym proces generowania wyrazów i ich syntagmatyczno-syntaktyczne uporządkowanie, które jako informacje samosterowne, przekazywane do efektorów, podlegają produkcji fonetyczno-fonematycznej albo graficzno-grafematycznej. Rozważając zatem cały ciąg przebiegu użycia języka przez nadawcę, należy wskazać raz na proces inicjujący komunikację w sferze lingwo-mentalnej, i drugi raz na złożony proces kodowania informacji w urządzeniu językowym, przebiegający najpierw w subprocesie generowania, a następnie w subprocesie produkowania w określonych efektorach ${ }^{12}$. Urzeczywistnienie intencji komunikacyjnej warunkują stan ilościowy poszczególnych struktur języka przyswojonych przez danego użytkownika oraz ich moc generatywna i produktywna, dzięki którym dochodzi do wytwarzania "nowych" (indywidualnych) informacji przez nadawcę, tzn. nie takich samych, które prezentuje podręcznikowy materiał bazowy, składający się z wybranych i glottodydaktycznie uporządkowanych struktur i stanowiących podstawę nauczania i uczenia się języków obcych.

Lubelski - Wydawnictwo, 1984, s. 16.

11 Por. także J. Piaget. Strukturalizm. Warszawa: Wiedza Powszechna, 1972, s. 124.

12 Szczegółowa charakterystyka wymienionych procesów i ich poszczególnych faz w artykułach: M. Szczodrowski. Zweistufige Dekodierung der fremdsprachlichen (Informations-)Signale. „Studia Niemcoznawcze” („Studien zur Deutschkunde”). Warszawa: Uniwersytet Warszawski, Instytut Germanistyki, 2013, t. 52, s. 299-306 oraz M. Szczodrowski. Zweistufige Kodierung fremdsprachlicher Informationen. „Studia Niemcoznawcze” („Studien zur Deutschkunde”). Warszawa: Uniwersytet Warszawski, Instytut Germanistyki, 2013, t. 52, s. 307-314. 
Do różnych form wypowiedzi danego użytkownika nawiązuje również René Dirven $^{13}$, wyróżniając ich trzy podstawowe typy w zakresie języka mówionego: (1) spontaniczne, (2) przygotowane i (3) niespontaniczne. Wśród pierwszych (spontanicznych) wyodrębnia wypowiedzi autentyczne i tzw. pozorno-autentyczne, a do autentycznych zalicza monologowe (opowiadania, sprawozdania), dialogowe (konwersacje) i multilogowe (rozmowy prowadzone w kilkuosobowej grupie), natomiast pozorne-autentyczne dzieli na dwie grupy, a mianowicie na wyuczone na pamięć i odczytane (np. wykłady, wiadomości, teksty literackie). W przygotowanych wypowiedziach wyróżnia, między innymi, wykład, kazanie, przemowę, mowę itp.

Powyższe przykłady wypowiedzi mają wskazać nie tylko na możliwości ich kodowania, lecz również na sposób ich audytywnego odbioru i zrozumienia. Zarówno proces produkcji językowej, jak i proces audytywnego odbioru i zrozumienia informacji językowych odznaczają się kompleksową strukturą, na którą składają się komponenty audytywno-fonetyczne, fonetyczno-fonologiczne, syntaktyczno-semantyczne, semantyczno-pragmatyczne i tekstowo-kognitywne.

\section{Podsumowanie}

Wspólną właściwością przedstawionych procesów jest ich stosowana substancja językowa, a ich zróżnicowanie dotyczy warunków i czasu ich przebiegu. Omówione procesy można scharakteryzować następująco:

1. W pierwszym przypadku proces przyswajania języka dokonuje się w naturalnych warunkach, w których jego użytkownicy posługują się nim w codziennych sytuacjach.

2. Drugi przypadek wskazuje na nauczanie i uczenie się, a w dalszej kolejności, na opano(wy)wanie danego języka (tu szczególnie języka obcego) w szkolnych i pozaszkolnych warunkach, gdzie ów proces podlega ogólnie przyjętym i realizowanym w praktyce zasadom edukacyjnego systemu nauki języków obcych. Proces taki nabiera stricte charakteru glottodydaktycznego.

3. Ostatnia sytuacja odnosi się do autodydaktycznego zaangażowania się o staranność i dbałość językową w odniesieniu do odbieranych, a przede wszystkich do własnych wypowiedzi i tekstów. Użytkownik języka jako odbiorca zazwyczaj szybciej dostrzega błędy gramatyczne, semantyczne, ortograficzne, interpunkcyjne lub niezgodności z obowiązującymi regułami w wypowiedziach lub tekstach swoich partnerów. Z drugiej strony użytkownik języka jako nadawca potrafi zauważyć również własne błędy, co należy uznać za specyficzny (i skuteczny) rodzaj lingwalnej autoglottodydaktyki, prowadzący do poprawnego władania językiem w odniesieniu do stosowanych struktur i ich dźwiękowej lub graficznej produkcji. Każda z wymienionych czynności wywołuje refleksję na temat popełnionego błędu albo pojawiającej się nieścisłości, a także jego/jej starannej korekty i zapamiętania popełnianego błędu oraz do utrwalenia prawidłowej formy językowej lub pogłębienia wiedzy o obowiązujących regułach i wyjątkach w danym języku.

13 R. Dirven. Was ist Hörverstehen? Synopse vorhandener Theorien und Modelle. [W:] Hrsg. A. Schumann, K. Vogel Klaus, B. Voss. Hörverstehen. Tübingen: Gunter Narr Verlag, 1984, s. 22. 


\section{Bibliografia}

Beeh V. Sprache und Spracherlernung. Unter mathematisch-biologischer Perspektive. Berlin-New York: Walter de Gruyter, 1981.

Dirven R. Was ist Hörverstehen? Synopse vorhandener Theorien und Modelle. [W:] A. Schumann, K. Vogel, B. Voss (Hrsg.). Hörverstehen. Tübingen: Gunter Narr Verlag, 1984, s. 19-40.

Felix S.W. Psycholinguistische Aspekte des Zweitsprachenerwerbs. Tübingen: Gunter Narr Verlag, 1982.

Górski K. Rozważania teoretyczne. Literatura - Muzyka - Teatr. Lublin: Katolicki Uniwersytet Lubelski - Wydawnictwo, 1984.

Jäger L. Einführung in die Sprachtheorie. „Linguistik und Didaktik” 1980, nr 41, s. 1-42.

Parreren C.F. van. Lernprozeß und Lernerfolg. Braunschweig: Georg Westermann Verlag, 1972.

Piaget J. Strukturalizm. Warszawa: Wiedza Powszechna, 1972.

Strohner H. Textverstehen, Kognitive und kommunikative Grundlagen der Sprachverarbeitung. Opladen: Westdeutscher Verlag, 1990.

Szczodrowski M. Zweistufige Dekodierung der fremdsprachlichen (Informations-)Signale. „Studia Niemcoznawcze” („Studien zur Deutschkunde”) 2013, t. 52. Warszawa: Uniwersytet Warszawski, Instytut Germanistyki, s. 299-306.

Szczodrowski M. Zweistufige Kodierung fremdsprachlicher Informationen. „Studia Niemcoznawcze” („Studien zur Deutschkunde”) 2013, t. 52. Warszawa: Uniwersytet Warszawski, Instytut Germanistyki, s. 307-314.

Vollmer H.J. Spracherwerb und Sprachbeherrschung. Tübingen: Gunter Narr Verlag, 1982.

Zabrocki L. Kybernetische Modelle der sprachlichen Kommunikation. Wrocław-Warszawa-KrakówGdańsk: Ossolineum, 1975. 